\title{
Assessment of Feed Supply and Demand for Livestock in Pakistan
}

\author{
Ghulam Habib $^{1}$, Muhammad Fatah Ullah Khan ${ }^{2}$, Shahbaz Javaid ${ }^{2}$ and Muhammad Saleem ${ }^{1}$ \\ 1. Animal Nutrition Department, University of Agriculture, Peshawar 2500, Pakistan \\ 2. Animal Sciences Institute, National Agricultural Research Center, Islamabad 44000, Pakistan
}

\begin{abstract}
Country level assessment of feed supply and demand for livestock in Pakistan was conducted for the year 2013. Availability of feed ingredients was calculated from the official crop production statistics using published harvest index and extraction ratios, and their nutrient supply was estimated from local feed composition tables. Feed requirements of livestock species were calculated from the standard tables published by US National Research Council. The results showed that indigenous feed resources were short for livestock and poultry requirements. The supply and demand gap for dry biomass, crude protein (CP) and metabolizable energy (ME) were 19.4\%, 37.2\% and 38.0\%, respectively. Crop residues were the predominant source comprising $58.8 \%$ of the total feed supply, while fodder and grazing shared $23.8 \%$ and $9.2 \%$, respectively. Grains and by-products contributed $8.2 \%$ to the feed supply. In attempt to fill this gap, large quantities of oilseed meals were imported mainly for the poultry sector. Maize was the major feed grain used in poultry and ruminant rations, and they together consumed 79\% of the country's total maize produce. Based on the anticipated rapid expansion in poultry, dairy and feedlot farming in Pakistan, the feed gap will further enlarge and this warrants future focus on efficient and intensive utilization of the local conventional and nonconventional feed resources. The data and information presented in this paper provided a sound basis for regular updating in future to attain sustainable growth of livestock sector in the country.
\end{abstract}

Key words: Livestock feed resource, feed inventory, feed demand, feed adequacy, Pakistan.

\section{Introduction}

Livestock production is an important component of agricultural activities in Pakistan, which has a strong agrarian base with vast tracts of cultivable land. Livestock including poultry contributes substantially to the national GDP, and within agriculture, the livestock sector has been claiming the largest share, contributing $55.9 \%$ to the agriculture value added and about $11.8 \%$ to the national GDP. Moreover, the value for livestock exceeds the combined value of all the major and minor crops by about 6.1\% [1]. Despite Pakistan holding huge livestock population of 181.2 million heads, the current supplies of animal proteins are inadequate to meet the human requirements, which are attributed to low animal productivity. Feed resources are the central components and drivers of

Corresponding author: Ghulam Habib, professor, research fields: feed utilization, dairy and beef animal nutrition. animal production systems, and the efficiency of use of the available feed resources is especially important as it is the primary determinant of animal performance and productivity [2]. Feed is recognized as the most important element of livestock production systems, forming up to $70 \%$ of the cost of production [3, 4]. Moreover, animal feed availability and utilization have multifaceted implications in term of farm economics, environment, product quality, product safety, animal health and animal welfare [5].

National level assessment of feed supply and demand in Pakistan is poorly characterized, and the data available are outdated, non comprehensive and less authenticated. Asia region is generally considered deficient in quality feed which does not match animal requirements $[2,6]$. The reality is that rapidly depleting resources in almost all Asian countries including Pakistan, such as arable land, water, fossil fuels, nitrogenous and other fertilizers, decreased 
supplies of cereal grains and climate change [2], are the major challenges to enhance animal feed supply for maximizing animal productivity.

In the face of increasing demand for animal source food, the role of livestock in Pakistan from the traditional dual and non-food purposes is decreasing and changing towards more specialized functions for producing milk, meat and other products. This is supported by advances in livestock breeding, feeding and management practices associated with intensification. At the same time, there are diminishing land resources and climate change threats to produce quality feed and fodder. The local feed resources are thus under increasing pressure to meet the demand for the growing animal population with a desire for higher productivity. Regular and correct assessment of national feed resources is therefore imperative for sustainable livestock development. Achieving the objectives of improved efficiency in feed resource use and increased productivity from animals as the future needs shall emphasize intensive use of biomass from the forage resources, crop residues, agro-industrial by-products and other non-conventional feed resources including fruits and vegetable wastes [7], and this is possible only when country has regular updated status on feed inventory, management and utilization.

According to Food and Agriculture Organization of the United Nations (FAO) [8], country level feed balance based on feed inventory data is important to facilitate planning within the livestock industry, for example, in determining how many animals can be supported or produced based on existing feed resources, and in identifying what feed resources would and could be developed to achieve production objectives. Such efforts will, in turn, translate into enhanced food security balanced with environmental sustainability. Additionally information on feed ingredients at the country level will enhance the efficiency and profitability of the animal feed industry and assist researchers to formulate relevant feeding strategies. Lack of updated national scale feed assessment in Pakistan has hindered policy decisions for planning sustainable development of the livestock sector and setting environmentally sustainable livestock stocking rate.

The present paper reported data and information on availability and utilization of indigenous feed resources in comparison to livestock and poultry demand on country scale in Pakistan for the year 2013. This information would be of great benefit to policy-makers, government agencies, development organizations and non-governmental organization (NGOs) for development and implementation of policies that will contribute to the sustainable growth of the livestock sector in Pakistan.

\section{Materials and Methods}

The data for calculating feed inventory and feed balance were derived from three major inputs: (1) feed resources from agricultural crops, (2) forages from the country's land classifications and (3) feed requirements based on national livestock census. The values on feed composition were taken from local feed composition tables compiled by Habib [9], and nutrient requirements in terms of dry matter (DM), crude protein (CP) and metabolizable energy (ME) were estimated from the standard tables published by US National Research Council for dairy cattle [10], sheep [11] and goats [12]. In the absence of the latest census data, the numbers of different categories of livestock were extrapolated from the changes in livestock population growth that occurred between the last two censuses conducted in 1996 and 2006 [13, 14].

The biomass of crop residues and other by-products of agricultural crops used as feed were calculated using the production data of main crops published by the Bureau of Statistics, Government of Pakistan [15]. The quantity of crop by-products was calculated using the harvest index or extraction ratios reported in Table 1. Most of these values are based on local findings taken from various publications of crop sector institutes. 
Table 1 Conversion factors of various feed resources from crops.

\begin{tabular}{|c|c|c|c|c|}
\hline Crops & Crop residues & Oilseed meals & Oilseed cakes & Bran/husk \\
\hline Wheat & 1.50 & & & 0.08 \\
\hline Rice & 1.50 & & & 0.08 (polishing 0.06 ) \\
\hline Maize & 3.00 & & 0.80 & 0.05 \\
\hline Sorghum & 4.00 & & & \\
\hline Millet & 4.00 & & & \\
\hline Barley & 1.50 & & & \\
\hline Gram & 4.00 & & & 0.06 \\
\hline Guar & 4.00 & & & \\
\hline Pulses & 4.00 & & & 0.03 \\
\hline Sugarcane & 0.25 & & & \\
\hline Groundnut & 2.00 & & & \\
\hline Cottonseed & & 0.35 & 0.80 & \\
\hline Rapeseed & & 0.58 & 0.70 & \\
\hline Canola & & 0.58 & 0.70 & \\
\hline Sunflower & & 0.58 & 0.70 & \\
\hline Sesame & 2.00 & & 0.70 & \\
\hline
\end{tabular}

Missing information was filled in by literature values reported for similar agro-climatic condition in the Asia Sub region [16, 17]. Feeds, such as grains, pulses and their by-products, oilseed meals/cakes and molasses, have multiple uses. The quantity of main crops/products used as animal feed and their inclusion level in livestock feed were estimated based on local practices and personal information collected from feed manufacturing industries and extension workers serving in different parts of the country.

The two main land categories include agricultural land used for fodder cultivation and grazing land reported by the statistical division [15]. The publication also provided data on annual production (acreage and yield) of cultivated summer and winter fodders in Pakistan. Forage supply from grazing lands was calculated according to FAO [18]. Finally, the feed balance was calculated by subtracting the nutrient requirements of livestock and poultry from those supplied by indigenous feed resources.

\section{Results and Discussion}

The main feed resources in Pakistan consist of crop residues, forages, grazing land, grains and industrial by-products of oilseeds and cereals. The relative share of these feed categories to the overall national feed supply is discussed later. Before assessing feed supply and demand, it is important to describe the profile of livestock assets in Pakistan.

\subsection{Livestock Population Profile}

In Pakistan, livestock census is conducted every 10 years with the recent past census performed in 2006. According to the earlier three census reports, the livestock number consistently increased and recorded an average annual growth of 2.3\% during 1996 to 2006 (Table 2). Based on the growth rate during the period from 1996 to 2006 [13, 14], livestock numbers in 2013 were estimated as cattle 38.3 million, buffalo 33.7 million, sheep 28.8 million, goats 64.9 million and camels 1.0 million. The rapid growth in livestock population has included Pakistan among the top 10 livestock holding countries and globally ranked Pakistan as the second in buffaloes, third in goats and ninth in cattle and sheep numbers [19]. The huge livestock population places enormous pressure on the country's declining land based feed resources. According to FAOSTAT [19], average livestock density as number per hectare agricultural land for large ruminants increased from 1.7 in 2000 to 2.4 in 2009 in 
Table 2 Livestock population in Pakistan and their growth rates over the last 30 years [13].

\begin{tabular}{|c|c|c|c|c|c|c|c|}
\hline \multirow{2}{*}{ Species } & \multicolumn{4}{|c|}{ Livestock population (million) } & \multicolumn{3}{|c|}{ Annual growth rate (\%) } \\
\hline & 1976 & 1986 & 1996 & 2006 & 1976-1986 & 1986-1996 & 1996-2006 \\
\hline Cattle & 14.9 & 17.1 & 20.4 & 29.6 & 1.5 & 1.9 & 4.5 \\
\hline Buffalo & 10.6 & 15.7 & 20.3 & 27.3 & 4.8 & 2.9 & 3.4 \\
\hline Goats & 21.7 & 29.0 & 41.2 & 53.7 & 3.4 & 4.2 & 3.0 \\
\hline Sheep & 18.9 & 22.6 & 23.5 & 26.4 & 2.0 & 0.4 & 1.2 \\
\hline Camels & 0.8 & 1.0 & 0.8 & 0.9 & 2.5 & $(-) 2.0$ & 1.3 \\
\hline Horses & 0.4 & 0.4 & 0.3 & 0.3 & 0.0 & $(-) 2.5$ & 0.0 \\
\hline Asses & 2.2 & 3.0 & 3.6 & 4.3 & 3.6 & 2.0 & 1.9 \\
\hline Mules & 0.1 & 0.1 & 0.1 & 0.2 & 0.0 & 0.0 & 10.0 \\
\hline
\end{tabular}

Pakistan. Similarly, the average number of sheep and goats per hectare agricultural land increased from 2.7 in 2000 to 3.3 in 2009.

The herd size distribution shows that livestock population in the country is highly fragmented. Half of the population (52\%) of both large and small ruminants is raised in small herd size of 1-6 cattle and buffaloes and 1-30 sheep and goats (Table 3). A similar pattern is also found for household ownership based on animal herd size, which provides a strong evidence for dominance of smallholder system in Pakistan. Over 84\% households have 1-6 cattle and buffaloes or 1-30 sheep and goats. This clearly indicates the significance of smallholder system in the rural economy of Pakistan. Although the genetic makeup of the local breeds is considered poor, their productive potential has never been achieved. Average animal productivity in smallholder system is almost one-third of the optimum level of the breed potential. This is primarily due to inadequate nutrition and associated health problems. The rising interest of farmers to substitute local cows with cross-bred (local $\times$ exotic blood) in an attempt to enhance milk production has witnessed limited success in smallholder farms because of poor feed supply from mixed livestock-crop and extensive systems which do not match with the high demand of quality feed for these animals. Annual increase in the country's milk and meat is essentially a reflection of increase in the number of animals rather than increase per animal productivity.
In contrast to livestock, poultry sector has shown remarkable growth over the last decade. This resulted from joint efforts of government and private sectors in promoting commercial poultry farming in the country. The number of domestic and commercial birds over the last three years is reported in Table 4. The remarkable growth in commercial poultry has significantly contributed to food security in Pakistan. Domestic poultry is a neglected segment in Pakistan and their numbers increased by $4.55 \%$ from 2010 to 2013, while commercial poultry exhibited $32.65 \%$ increase during the same period [20]. The rising trend in poultry meat supply that increased from 349,000 tonnes in 2003 to 907,000 tonnes in 2013 suggests that in future poultry meat consumption will outpace mutton consumption in the country. However, the sustainability of poultry industry would depend on feed availability especially grains, which is in direct competition with humans, dairy and beef sectors.

\subsection{Feed Availability}

Major domestic feed resource categories and their quantities are summarized in Table 5. Crop residues supply (58.8\%), which constitutes the bulk of feed DM, is followed by fodder (23.8\%). Grazing shares 9.2\% of the feed DM supply. The remaining 8.2\% DM is contributed by grains and agro-industrial by-products. Feed availability is not constant in different parts of the country and varies considerably [21]. In Baluchistan province that has vast rangelands and limited cultivated land, grazing serves as the dominant 
Table 3 Livestock numbers by herd/flock size in Pakistan during 2006 [13].

\begin{tabular}{llllll}
\hline \multirow{2}{*}{ Herd size } & \multicolumn{3}{c}{ Numbers (million) } & \multirow{2}{c}{ Flock size } & Numbers (million) \\
\cline { 2 - 4 } & Cattle & Buffalo & & Sheep & Goat \\
\hline $1-6$ & $14.9(50.3)$ & $14.4(52.7)$ & $1-30$ & $9.9(37.4)$ & $36.2(67.3)$ \\
$7-15$ & $7.7(26.1)$ & $7.8(28.6)$ & $31-75$ & $5.5(20.8)$ & $7.8(14.5)$ \\
$16-50$ & $3.3(11.1)$ & $3.2(11.7)$ & $76-350$ & $6.9(26.0)$ & $6.5(12.1)$ \\
$>50$ & $3.7(12.5)$ & $1.9(7.0)$ & $>350$ & $4.2(15.8)$ & $3.3(6.1)$ \\
\hline Total & $29.6(100.0)$ & $27.3(100.0)$ & Total & $26.5(100.0)$ & $53.8(100.0)$ \\
\hline
\end{tabular}

Values in parentheses are \% of the total.

Table 4 The poultry population trend in Pakistan [20].

\begin{tabular}{llllll}
\hline \multirow{2}{*}{ Poultry } & \multicolumn{4}{c}{ Poultry population (millions) } & Increase of \\
\cline { 2 - 5 } & $2009-2010$ & $2010-2011$ & $2011-2012$ & $2012-2013$ & $2010-2013$ (\%) \\
\hline Domestic poultry & 77.35 & 78.51 & 79.68 & 80.87 & 4.55 \\
Commercial poultry & $1,047.56$ & $1,150.98$ & $1,264.67$ & $1,389.62$ & 32.65 \\
Layers & 30.41 & 32.54 & 34.82 & 37.25 & 22.49 \\
Broilers & 493.40 & 542.74 & 597.02 & 656.72 & 33.10 \\
Breeding stock & 8.39 & 8.81 & 9.25 & 9.71 & 15.73 \\
Day old chicks & 515.36 & 566.89 & 623.58 & 685.94 & 33.10 \\
\hline
\end{tabular}

Table 5 Contribution of main feed categories to total feed availability.

\begin{tabular}{llll}
\hline Feed source & $\begin{array}{l}\text { Dry biomass } \\
\left(\times 10^{3} \text { tonnes }\right)\end{array}$ & $\begin{array}{l}\text { Crude protein } \\
\left(\times 10^{3} \text { tonnes }\right)\end{array}$ & $\begin{array}{l}\text { Metabolizable energy } \\
\left(\times 10^{10} \mathrm{MJ}\right)\end{array}$ \\
\hline Crop residues & $68,984(58.8)$ & $2,828(32.6)$ & $45.64(49.3)$ \\
Oil cakes/meals and cereal brans & $4,975(4.2)$ & $872(10.1)$ & $5.57(6.0)$ \\
Grazing & $10,736(9.2)$ & $1,112(12.8)$ & $9.34(10.1)$ \\
Fodders & $27,898(23.8)$ & $3,297(38.0)$ & $25.97(28.0)$ \\
Grains & $4,714(4.0)$ & $565(6.5)$ & $6.09(6.6)$ \\
\hline Total & $117,307(100.0)$ & $8,674(100.0)$ & $92.60(100.0)$ \\
\hline
\end{tabular}

Values in parentheses are \% of respective total.

feed source and supplies 66\% feed DM, followed by crop residues taking $25 \%$ of the province feed supply. Conversely, in the other three provinces Punjab, Sindh and Khyber Pakhtunkhwa, crop residues are classified as the major feed and constitute $55 \%-66 \%$ of the feed inventory with variable proportions $9 \%-28 \%$ supplied by cultivated fodder, and the least contribution (2\%-20\%) comes from grazing lands. Such unequal distribution of feed resources among different parts of the country is causing large movements of feedstuffs within the country in support of different livestock production systems.

\subsection{Crop Residues}

Bulk of the feed supply for ruminant livestock is derived from crop residues. Main categories include cereal straws, stovers and legume crop by-products, which collectively make $58.8 \%$ of the feed resource base of Pakistan with a total availability of 68.98 million tonnes annually. However, due to inherited poor quality, crop residues contribute one-third to total CP and nearly make half of the total ME supply (Table 5).

The availability of different crop residues is reported in Table 6. The major part of the total crop residues (64\% or 44.18 million tonnes) is contributed by cereal straws, predominantly wheat straw (36.32 million tonnes), followed by $20.87 \%$ shared by cereal stovers. Legume straw constitutes only a small fraction (6\%) of the available crop residues. Wheat crop is cultivated all over the country, yielding a great quantity of wheat straw, and constitutes half of the 
Table 6 Availability of crop residues from major crops.

\begin{tabular}{|c|c|c|c|c|}
\hline \multirow{2}{*}{ Category } & \multirow{2}{*}{ Crops } & \multicolumn{2}{|c|}{ Crop residue dry matter yield } & \multirow{2}{*}{-Regions/zones } \\
\hline & & $\times 10^{3}$ tonnes & $\%$ & \\
\hline \multirow{4}{*}{ Straw } & Rice & 7,764 & 11.26 & Irrigated \\
\hline & Wheat & 36,317 & 52.66 & Irrigated, arid, semi-arid \\
\hline & Barley & 101 & 0.15 & Irrigated \\
\hline & Sub-total & 44,182 & 64.06 & \\
\hline \multirow{4}{*}{ Stovers } & Maize & 12,660 & 18.36 & Irrigated \\
\hline & Millet & 1,242 & 1.80 & Arid and semi-arid \\
\hline & Sorghum & 490 & 0.71 & Arid and semi-arid \\
\hline & Sub-total & 14,393 & 20.87 & \\
\hline \multirow{3}{*}{ Legumes } & Pulses & 3,591 & 5.21 & Arid and semi-arid \\
\hline & Guar & 598 & 0.87 & Arid and semi-arid \\
\hline & Sub-total & 4,190 & 6.07 & \\
\hline \multicolumn{2}{|c|}{ Sugarcane/sugar beet } & 5,602 & 8.12 & Irrigated \\
\hline \multicolumn{2}{|l|}{ Oilseed } & 600 & 0.87 & Irrigated, arid, semi-arid \\
\hline \multicolumn{2}{|c|}{ Grand total } & 68,966 & 100.00 & \\
\hline
\end{tabular}

Table 7 Land use pattern for fodder cultivation in Pakistan [15].

\begin{tabular}{lll}
\hline Period & Area $\left(\times 10^{3}\right.$ ha) & Change relative to 1980-1985 (\%) \\
\hline $1980-1985$ & 2,770 & \\
$1985-1990$ & 2,753 & $(-) 0.60 \%$ \\
$1990-1995$ & 2,698 & $(-) 2.60 \%$ \\
$1995-2000$ & 2,650 & $(-) 4.40 \%$ \\
$2000-2005$ & 2,460 & $(-) 11.20 \%$ \\
$2005-2010$ & 2,418 & $(-) 12.70 \%$ \\
$2010-2013$ & 2,157 & $(-) 22.13 \%$ \\
\hline
\end{tabular}

available crop residues. Wheat straw is one of the most common roughage sources in traditional feeding system, especially in smallholder farming. Maize stover is the second popular crop by-product offered to livestock in irrigated areas. Sorghum and millet are cultivated in arid and semi-arid regions, and after harvesting grains, the stovers are stored as feed. Under conventional feeding in smallholder systems, crop residues are offered to livestock all year round either alone or mixed with green fodder, and its daily use peaks during the lean periods substituting green fodder. Trading and movement of wheat straw among different parts of the country is frequent, and the price has escalated more than five times over the past two decades.

\subsection{Fodder}

Fodder contributes $23.8 \%$ to the feed supply and serves as the second large feed source after crop residues. Its share in total feed $\mathrm{CP}$ and ME supply is $38 \%$ and 28\%, respectively (Table 5). On average, only $6.5 \%$ of the cultivated land or 2.1 million ha is used for growing fodder in Pakistan, and the distribution varies substantially in different agro-ecological zones depending on availability of cultivatable land, water for irrigation, land tenure system and access to other alternative resources, such as grazing land. Land for fodder cultivation has progressively decreased during the last three decades (Table 7) with a decrease of $22.13 \%$ recorded during 2010-2013 compared with 1980-1985 as the base year. However, this trend is apparently compensated by the new trends in vertical increase in fodder cultivation during the recent years, as farmers are now inclined to using high yielding fodder varieties introduced by multinational companies in Pakistan. Hybrid maize 
fodder is cultivated for silage preparation in dairy pockets. Aside the 12.4 tonnes local fodder seeds supplied, about 10,064 tonnes imported fodder seeds were available during 2012-2013 [20].

While fodder yield is constrained by decreasing arable land and higher priority for growing food and cash crops, the overall fodder yield also remained low with little change beyond an average of 40 tonnes fresh matter/hectare over the last decade. Local research has identified a large gap between fodder yield with improved agronomic management and that produced using conventional practices. It is possible that fodder production could be increased two to three fold per unit of land with improved seeds and agronomic practices [22]. Inaccessibility of farmers to quality seeds is a major constraint. Overall, the technology of improved forages has been slow to reach the rural small scale farms, and both forages and seed production have lagged behind the demand.

Common fodders grown during winter (October through May) include barseem (Trifolium alexandrinum), barley (Hordeum vulgare), mustard/rape (Brassica spp.), oats (Avena sativa) and raya (Brassica juncea). Summer fodders (May through September) are cowpea (Vigna unguiculata), guar (Cyamopsis tetragonoloba), jantar (Dhaincha), maize (Zea mays), millet (Pennisetum typhoides), moth (Phaseolus aconitifolius), mung (Vigna radiata), Napier grass, sorghum (Sorghum bicolor), sudex (Sadabahar) and swank (Pennisetum glaucum).

Cultivation of perennial fodder is not popular. The climate of the irrigated tracts, with its large variation in seasonal temperature, is not well suited to perennial fodders. Only two species, lucerne (Medicago sativa) and mott grass (Pennisetum purpureum) are cultivated in canal and tube well irrigated areas. Lucerne is popular in the northern region with perennial water for irrigation. It is converted to hay and used for winter feeding. However, its yield and quality are quite low under traditional farming systems.

Calculations in this paper show that currently, the available quantity of fodder hardly satisfies $40 \%$ of the annual fodder requirements of the country's livestock population. In an area where land and irrigation are the major limiting factors to agricultural production, intensification is the only way to meet the country's needs for forage and livestock products. The compatibility of local fodder varieties in the face of climate change is decreasing, and the solution would be to look for climate resilient fodder varieties especially for arid and semi-arid regions.

\subsection{Grazing}

Rangeland is spread over 79.47 million ha, constituting $53 \%$ of the geographical area in four provinces of Pakistan (Table 8). These rangelands together with other grazing lands provide a substantial part of the national livestock feed resources base in arid, semi-arid and mountainous regions. Grazing shares $8.6 \%$ of the total feed resource DM supply, but its contribution is not uniform over the four provinces. In Baluchistan province which is predominantly arid, desert and mountainous, grazing is the major feed resource and provides $63 \%$ of the province feed supply. Conversely, grazing contributes 2\%, 15\% and 23\% to the feed supply in Punjab, Sindh and Khyber

Table 8 Distribution of rangelands in Pakistan [18].

\begin{tabular}{llllll}
\hline Provinces & $\begin{array}{l}\text { Total area } \\
\left(\times 10^{6} \mathrm{ha}\right)\end{array}$ & $\begin{array}{l}\text { Rangeland area } \\
\left(\times 10^{6} \mathrm{ha}\right)\end{array}$ & $\begin{array}{l}\text { Rangeland } \\
(\%)\end{array}$ & $\begin{array}{l}\text { Average yield } \\
(\mathrm{kg} \mathrm{DM} / \mathrm{ha})\end{array}$ & $\begin{array}{l}\text { Average improvement } \\
\text { potential (kg DM/ha) }\end{array}$ \\
\hline Punjab & 20.63 & 8.35 & 40.48 & $300-1,500$ & up to 2,000 \\
Sindh & 14.00 & 7.85 & 56.07 & $400-600$ & up to 2,000 \\
Khyber Pakhtunkhwa & 10.12 & 5.60 & 55.34 & $600-1,800$ & 1,300 to 2,200 \\
Balochistan & 34.72 & 21.00 & 60.48 & $300-500$ & 800 to 2,000 \\
\hline Total/mean & 79.47 & 42.80 & 53.09 & & \\
\hline
\end{tabular}


Pakhtunkhwa provinces of Pakistan, respectively. Despite the vast rangelands of 79.47 million ha, its share in feed supply is relatively low. Current level of average forage production is $300-1,800 \mathrm{~kg} / \mathrm{ha}$ compared to the potential of over $2,000 \mathrm{~kg} / \mathrm{ha}$ [18] with a higher potential of improvement in the rangelands, especially in Baluchistan (Table 8).

Rangelands in Pakistan are gradually shrinking at about $2 \%$ per annum. Of more concern is the progressive decrease in vegetation cover of heterogeneous composition in these lands. The foliage cover of grasses and vegetation has decreased up to $40 \%$ [23]. Frequent droughts, low rain fall, uncontrolled grazing and absence of a relevant strategy for rehabilitation are major causes of rangeland deterioration and have several socio-economic and environmental implications, which have made pastoralists more vulnerable. Not only the carrying capacity of grazing land is continuously decreasing, the disappearance of palatable grass species replaced by shrubs is also increasingly noticed. Associated with these are the changes in herd composition with higher proportion of goats compared with sheep, forced reduction in flock size and greater exposure to diseases due to extensive travelling for grazing.

\subsection{Grains and By-products}

In Pakistan, 4.7 million tonnes of grains are used as feed for ruminant livestock and poultry. Grains constitute a small portion (4.0\%) of the total feed supply. Availability and use of different grains as feed is summarised in Table 9. Wheat is a staple human food, and its use in poultry and dairy rations is the minimum due to high cost. Maize is the choice feed grain, and it has been calculated that almost 79\% (3.33 million tonnes) of the 4.22 million tonnes of maize produced is annually utilized in poultry and livestock rations. The poultry sector consumes the bulk of maize supply. The total annual grains consumption by commercial poultry is estimated at 4.23 million tonnes, and of this 2.42 million tonnes or $57 \%$ is met from maize. Both commercial and farm mixed cattle feed also utilise maize as the principal source of energy in concentrate rations. Dairy and beef sectors annually consume approximately 1.04 million tonnes of maize or $25 \%$ of the crop produced. With the rapid expansion of the poultry, dairy and feedlot sector, it would be difficult for the indigenous maize supply to cater for the demand of feed grains. Currently, inclusion of broken rice in poultry rations has reduced to less than $3 \%$ compared to $10 \%$ in the past 10 years. Broken rice is now mostly used in the preparation of branded human food, and as such its price has gone up, so made it unaffordable as animal feed. Use of other cereal grains, such as sorghum and millet, is limited because of their low availability and anti-nutritional factors especially for poultry (Table 9).

Several by-products of grains and the food industry are utilized in livestock feeding depending on their

Table 9 Quantity of grains produced in the country and percentage available as livestock and poultry feed.

\begin{tabular}{lllll}
\hline \multirow{2}{*}{ Grain } & Yield & \multicolumn{3}{c}{ Availability as feed } \\
\cline { 3 - 5 }$\left(\times 10^{3}\right.$ tonnes $)$ & $\%$ & $\times 10^{3}$ tonnes & Relative proportion (\%) \\
\hline Wheat & 24,211 & 5 & 1,211 & 25.7 \\
Rice broken & 828 & 7 & 58 & 1.2 \\
Barley & 67 & 20 & 13 & 0.3 \\
Maize & 4,220 & 79 & 3,334 & 70.7 \\
Millet & 311 & 15 & 47 & 1.0 \\
Sorghum & 123 & 30 & 37 & 0.8 \\
Gram (chick pea) & 751 & 2 & 15 & 0.3 \\
\hline Total & 30,511 & & 4,714 & 100.0 \\
\hline
\end{tabular}


availability and prices. Almost one-third of the conventional dairy concentrate mixtures are composed of grain by-products. They are mostly fibrous in nature and are relatively inexpensive. Wheat bran is one of the most popular ingredients invariably used by almost all livestock farmers, followed by rice polishing and rice bran. Of the domestic supply of 1.94 million tonnes wheat bran, $70 \%$ is used in ruminant feed and the remaining is utilized in poultry rations. Conversely, a maximum of $90 \%$ of the rice polishing stock is incorporated in poultry feed. Local rice milling industry is producing 0.30 million tonnes rice polishing annually. In addition, various by-products/wastes of food and fruit industry are sporadically utilized as animal feed around big cities in Pakistan, but the type, availability and utilization pattern are not documented. Similarly, by-product of pulses from the milling industry in the form of a mixture of hulls and wasted parts of legume seeds is also used in ruminant feeding, and its annual supply is estimated at 49,000 tonnes.

\subsection{Oilseed By-products}

Oilseed by-products, such as oilseed cakes and oilseed meals, are protein rich feeds and serve as an essential part of the dairy and feedlot rations. These are relatively expensive and constitute $30 \%$ to $50 \%$ of the feed supplement. Oilseed cakes are mostly offered to ruminant livestock, while oilseed meals due to low fiber contents are mostly included in poultry rations.
The availability and utilization of different oilseed cakes and meals in ruminant and poultry feeding are reported in Table 10.

Domestic production of 1.27 million tonnes of oilseed cake and oilseed meal can not fully meet the combined requirements of these protein sources for ruminant livestock and poultry. Poultry rations generally include $25 \%$ oilseed meals as protein source, which means that about 1.19 million tonnes oilseed meal as against the domestic supply of 0.355 million tonnes is required. The deficiency is met by importing large quantities of oilseed meals. During 2012-2013, Pakistan imported 1.01 million tonnes of oilseed meals consisting of soybean meal 0.91 million tonnes and rapeseed meal 0.10 million tonnes [24]. Apart from this, 1.97 tonnes of sunflower seeds were also imported during the same year that also contributed to the availability of oilseed meals. In Pakistan, commercial dairy feed production is increasing at an accelerated pace to meet the demand for the expanding large dairy units that rely on high milk yielding animals. These animals require balanced feeds that demand the inclusion of protein meals in addition to traditional oilseed cakes to meet the rations need of high protein content. In Pakistan, presently there is an increasing trend in the requirements for protein meals due to the anticipated expansion of the poultry, dairy, feedlot and aquaculture sectors. The poultry feed industry has shifted from the use of animal origin protein meals due to the risk of disease,

Table 10 Production and use of oilseed cakes/meals in Pakistan during 2012-2013.

\begin{tabular}{llll}
\hline \multirow{2}{*}{ Feed } & Yield & Used as feed $\left(\times 10^{3}\right.$ tonnes $)$ & \\
\cline { 2 - 4 } & $\left(\times 10^{3}\right.$ tonnes $)$ & Ruminants & Poultry \\
\hline Cottonseed cake & 537 & $537(62.3 \%)$ & 0 \\
Rapeseed cake & 46 & $46(5.4 \%)$ & 0 \\
Sunflower cake & 4 & $4(0.4 \%)$ & 0 \\
Maize-oil cake & 219 & $219(25.5 \%)$ & 0 \\
Cottonseed meal & 23 & $23(2.7 \%)$ & 0 \\
Rapeseed meal & 89 & 0 & $89(25.2 \%)$ \\
Sunflower meal & 138 & 0 & $138(39.0 \%)$ \\
Maize gluten feed/meal & 159 & $32(3.7 \%)$ & $127(35.8 \%)$ \\
\hline Total & 1,217 & $862(100.0 \%)$ & $355(100.0 \%)$ \\
\hline
\end{tabular}


Table 11 Availability of feed in comparison to livestock requirements during 2012-2013.

\begin{tabular}{lllll}
\hline Feed components & Requirements & Availability & Sufficiency (\%) & Deficit \\
\hline Dry biomass $\left(\times 10^{3}\right.$ tonnes) & 154,181 & 124,328 & 80.6 & 29,853 \\
Crude protein $\left(\times 10^{3}\right.$ tonnes) & 15,033 & 9,442 & 62.8 & 5,591 \\
Metabolizable energy $\left(\times 10^{11} \mathrm{MJ}\right)$ & 15.76 & 9.77 & 62.0 & 5.99 \\
\hline
\end{tabular}

and now relies more on vegetable source meals. This in turn is spiking the demand for soybean meal by including $10 \%-15 \%$ soybean meal against the traditional $5 \%-7 \%$ in poultry feeds.

In line with such escalating demand, there was a sharp record increase in import of soybean meal of 910,000 tonnes in 2013 against 275,000 tonnes in 2010, showing more than a three-fold increase over the last three years. Palm kernel cake and meal is another protein feed that witnessed rising import from Malaysia due to its lower cost than the indigenous protein sources. Recently, a memorandum of understanding was signed, which will secure Pakistan as an importer of palm kernel meal from Malaysia. The current import of palm kernel cake from Malaysia has exceeded 73,000 tonnes annually.

\subsection{Feed Balance-Demand vs. Supply}

Feed balance calculation summarized in Table 11 shows that the domestic feed supply in Pakistan is short of the combined requirements for ruminant livestock and poultry. The indigenous feed resources are short of biomass (DM) of 29,853,000 tonnes, CP of 5,591,000 tonnes and $\mathrm{ME}$ of $5.99 \times 10^{11} \mathrm{MJ}$, corresponding to $19.36 \%, 37.19 \%$ and $38.0 \%$ deficiencies, respectively. With the expected increase in livestock and poultry intensification, the demand for animal feed will further increase in future, which will be in the face of shrinking agricultural land and add to the widening of the existing feed gap. Earlier, Sarwar et al. [25] reported a deficiency of $24 \%$ in total digestible nutrients and 34\% in digestible CP for livestock feeding in Pakistan. However, their calculation did not include the poultry sector. The present paper for the first time has comprehensively estimated feed supply and demand combined for ruminant livestock and poultry in Pakistan for the year 2013.

While the commercial poultry sector caters for the nutrient needs through imported feed ingredients, the livestock sector mostly relies on indigenous feed resources and thus largely suffers from nutrient deficiency. This is turn may explain the low yields of existing livestock in the rural smallholder system. In Pakistan, there is a rapid trend towards intensive urban and peri-urban dairy farming relying mostly on import of exotic cows and keeping cross bred dairy animals for obtaining high milk yield in parallel to increasing demand for milk in the local market. This together with increasing inclination for feedlot farming will add to the problem of feed inadequacy. These high yielding animals have greater feed demand, thus exerting pressure on indigenous sources with deficiencies met through increasing import of animal feed. Simultaneously, the poultry industry is also expanding rapidly, as it is able to provide a relatively cheap protein source for the growing human population. This would create a situation where livestock sector will be directly competing with commercial poultry for quality feed, such as oilseed meals and grains. Unless the country focuses on increasing the local production of these feed resources on priority basis, the dependency on using imported feed will increase.

Considering feed as the foundation of livestock and poultry development and its cost accounting up to $70 \%$ of the cost of farm operations [3, 4], measures to enhance indigenous feed supply require both policy and technical decisions. Long term thinking would require considering both intensive and smallholder production systems, and focusing on enhancement of feeds and feeding using innovation and value chain 
approaches to maximize feed production, feed use efficiency and at the same time minimize feed wastage. At present, there is high demand for food of animal origin in the country, but this realization is not translated into policy decisions, as to how such increasing livestock feed demand can be met from the shrinking agricultural and deteriorating grazing lands for achieving the production objectives. It is therefore imperative that the country as part of the national food security policy and planning shall conduct regular assessment of current and future feed supplies and demand by establishing a national feed assessment system under the existing Federal Animal Husbandry Commission. According to FAO [8], a national feed assessment system is a complete set of procedures, facilities, tools, personnel, organizations and institutions involved in the collecting, handling and processing of data necessary to calculate and report the supplies of livestock feeds from all sources and for all livestock types in a country.

\section{Conclusions}

The present findings suggested that indigenous feed resources in Pakistan are short for livestock and poultry requirements by $19.4 \%$ in terms of dry biomass with marked deficiency $37.2 \%$ and $38.0 \%$ for $\mathrm{CP}$ and ME, respectively. Most of the local feeds were of poor quality with crop residues, as the predominant source sharing $58.8 \%$ to the total feed supply. Fodder and grazing contributed $23.8 \%$ and $9.2 \%$, respectively, to the total feed supply, while grains and agro-industrial by products together added $8.2 \%$ to the supply. The country imported large quantity of oilseed meals especially for poultry sector to fill the feed gap. Maize was found to be the major feed grain for both poultry and ruminant rations, and together consumed almost $79 \%$ of the country's total maize produce. The future expansion in livestock, dairy and poultry industries in Pakistan would impose further pressure on country's feed resource base. There should therefore be policy decisions on the way forward to meet the future feed supply challenges that the anticipated expansion in livestock, dairy and poultry industries in Pakistan would impose for sustainable livestock production.

\section{References}

[1] Government of Pakistan. 2015. "Economic Survey of Pakistan, 2014-2015.” Economic Advisor's Wing, Finance Division, Government of Pakistan, Islamabad, Pakistan. Accessed August 10, 2016. http://www.finance.gov.pk/survey/chapters_15/02_Agric ultre.pdf.

[2] Devendra. C., and Leng, R. A. 2011. "Feed Resources for Animals in Asia: Issues, Strategies for Use, Intensification and Integration for Increased Productivity.” Asian-Aust. J. Anim. Sci. 24 (3): 303-21.

[3] Buza, M. H., Holden, L. A., White, R. A., and Ishler, V. A. 2014. "Evaluating the Effect of Ration Composition on Income over Feed Cost and Milk Yield.” J. Dairy Sci. 97 (5): 3073-80.

[4] Makkar, H. P. S. 2013. "Towards Sustainable Animal Diets.” In Optimization of Feed Use Efficiency in Ruminant Production Systems, edited by Makkar, H. P. S., and Beever, D. Rome: FAO and Asian-Australasian Association of Animal Production Societies, 67-74.

[5] Makkar, H. P. S. 2016. "Animal Nutrition in a 360-Degree View and a Framework for Future R\&D Work: Towards Sustainable Livestock Production.” Animal Production Science 56 (10): 1561-8.

[6] Habib, G., Makkar, H. P. S., and Otte, J. 2014. "Feed Resources in Upcoming Asia.” All about Feed 22 (9): 28-9.

[7] Wadhwa, M., and Bakshi, M. P. S. 2013. "Utilization of Fruit and Vegetable Wastes as Livestock Feed and as Substrates for Generation of Other Value-Added Products.” FAO, Rome. Accessed September 10, 2016. http://www.fao.org/docrep/018/i3273e/i3273e.pdf.

[8] Food and Agriculture Organization of the United Nations (FAO). 2012. "Guidelines for the Development of National Feed Assessment Systems (NFASs) and the Implementation of National Feed Assessments (NFAs).” In Conducting National Feed Assessments, edited by Coughenour, M. B., and Makkar, H. P. S. Rome, Italy: FAO.

[9] Habib, G. 2010. Nutrient Composition of Common Local Feeds. (Unpublished)

[10] National Research Council (NRC). 1989. Nutrient Requirements of Dairy Cattle, 6th ed.. Washington, DC: NRC, National Academy of Sciences.

[11] National Research Council (NRC). 1985. Nutrient 
Requirements of Sheep, 6th ed.. Washington, DC: NRC, National Academy of Sciences.

[12] National Research Council (NRC). 1981. Nutrient Requirements of Goats. Washington, DC: NRC, National Academy of Sciences.

[13] Government of Pakistan. 2006. "Livestock Census Pakistan.” Statistical Division, Government of Pakistan. $\begin{array}{llll}\text { Accessed July } & 14,\end{array}$ http://www.pbs.gov.pk/content/pakistan-livestock-census -2006 .

[14] Government of Pakistan. 1996. "Livestock Census Pakistan.” Statistical Division, Government of Pakistan.

[15] Government of Pakistan. 2013. "Agricultural Statistics of Pakistan, 2012-2013.” Statistical Division, Government of Pakistan. Accessed August 10, 2016. http://www.pbs.gov.pk/agri-stat-tables.

[16] Anandan, S., and Sampath, T. K. 2012. "The Indian Feed Inventory.” In Conducting National Feed Assessments, edited by Coughenour, M. B., and Makkar, H. P. S. Rome, Italy: FAO.

[17] Singh, K., Habib, G., Siddiqui, M. M., and Ibrahim, M. N. M. 1997. "Dynamics of Feed Resources in Mixed Farming Systems in South Asia.” In Crop Residues in Sustainable Mixed Crop-Livestock Farming Systems, edited by Renard, C. Wallingford, UK: CAB International.

[18] FAO. 2013. Current Status of Rangelands in Pakistan. A Consultation Process. (Unpublished)

[19] FAOSTAT. 2015. “Live Animals.” Food and Agriculture Organization, the United Nations. Accessed September
09, 2016. http://faostat3.fao.org/home/E.\%20A.

[20] Government of Pakistan. 2013. "Economic Survey of Pakistan, 2012-2013.” Economic Advisor's Wing, Finance Division, Islamabad, Pakistan. Accessed August 10, 2016. http://www.finance.gov.pk/survey/ chapters_13/02-Agriculture.pdf.

[21] Habib, G. 2008. "Best Practices in Animal Feed Production and Management in Pakistan.” In Best Practices in Animal Feed Production and Management in SAARC Countries, edited by Huque, K. S., Kabir, W., and Akter, N. Dhaka, Bangladesh: SAARC Agriculture Centre.

[22] Dost, M. 2003. "Fodder Production for Peri-urban Dairies in Pakistan.” Accessed August 12, 2016. http://www.fao.org/ag/agp/agpc/doc/pasture/dost/fodderd ost.htm.

[23] Government of Pakistan. 2010. "National Rangeland Policy." Ministry of Environment, Government of Pakistan. Accessed August 23, 2016. http://waterinfo.net.pk/sites/default/files/knowledge/Nation al\%20Rangeland\%20Policy\%202010\%20-\%20Draft.pdf.

[24] USDA Foreign Agricultural Services. 2015. "Pakistan Oilseeds and Products Annual Gain Report No. PK1515.” Accessed August 14, 2016. http://gain.fas.usda.gov/Recent\%20GAIN\%20Publication s/Oilseeds\%20and\%20Products\%20Annual_Islamabad_P akistan_4-1-2015.pdf.

[25] Sarwar, M., Khan, M. A., and Iqbal, Z. 2002. "Feed Resources for Livestock in Pakistan.” Int. J. Agri. Biol. 4 (1): 186-92. 